\title{
PROTOTIPE SISTEM MONITORING PENGGUNAAN DAYA LISTRIK PERALATAN ELEKTRONIK RUMAH TANGGA BERBASIS INTERNET OF THINGS
}

\author{
Budi Prayitno $^{1}$, Pritasari Palupiningsih ${ }^{2}$, dan Herman Bedi Agtriadi ${ }^{3}$ \\ ${ }^{1,2,3}$ Sekolah Tinggi Teknik PLN \\ E-mail: $\underline{\text { budiprayitno@sttpln.ac.id }}$
}

\begin{abstract}
Power consumption of PLN customers from household sector is quite large. It comes from the use of household appliances, such as refrigerators, televisions, dispensers, lights and air conditioners. The customers assume that their electricity usage is wasteful, but unfortunately it couldn't be known in detail which household electrical appliances spend the most electricity. So that, difficult for the customers to monitor the power usage of each household electrical equipments. Regarding to this issue, this research focused on making a prototype of a household electrical power usage monitoring system. This system can be used by PLN customers of households sector to find out which household appliances use large power, so that the customers can manage the use of household appliances. In implementing that monitoring, it needs a capable wattmeter devices to measure the power usage of household electronic equipments The results of this measurement electric current, voltage, and power data measured through sensors. Those measurement data is sent to the database server system monitoring through the internet of things (IoT) device so that monitoring can be done through the system in a real time. This study produced a prototype of household electronic equipments power usage monitoring system based on IoT.
\end{abstract}

Keywords: Internet of things, monitoring, wattmeter, household electricity

\begin{abstract}
ABSTRAK
Konsumsi daya pelanggan PLN dari sektor rumah tangga berjumlah cukup besar, yaitu berasal dari penggunaan peralatan rumah tangga, seperti kulkas, televisi, dispenser, lampu dan AC. Pelanggan merasa penggunaan listrik mereka boros, akan tetapi tidak dapat diketahui secara detail peralatan listrik rumah tangga mana saja yang menghabiskan daya listrik paling besar. Hal ini membuat pelanggan sulit untuk memantau penggunaan daya dari setiap peralatan listrik rumah tangga. Untuk itu penelitian ini fokus untuk membuat prototipe sistem monitoring penggunaan daya listrik peralatan rumah tangga. Sistem ini dapat dimanfaatkan pelanggan PLN sektor rumah tangga untuk mengetahui peralatan rumah tangga mana saja yang menggunakan daya besar, sehingga pelanggan dapat mengatur penggunaan peralatan rumah tangga tersebut. Untuk melakukan monitoring tersebut, maka diperlukan perangkat wattmeter yang mampu mengukur penggunaan daya peralatan elektronik rumah tangga. Hasil pengukuran ini berupa data arus, tegangan dan daya yang terukur melalui sensor. Agar monitoring dapat dilakukan melalui sistem secara real time, maka data pengukuran tersebut dikirimkan ke database server sistem monitoring melalui perangkat internet of things (IoT). Penelitian ini menghasilkan prototipe sistem monitoring penggunaan daya peralatan elektronik rumah tangga berbasis IoT.
\end{abstract}

Kata kunci: Internet of things, monitoring, wattmeter, listrik rumah tangga 


\section{PENDAHULUAN}

Konsumsi daya pelanggan PLN dari sektor rumah tangga berjumlah cukup besar. Berdasarkan Catatan Statistik Ketenagalistrikkan 2016 yang dikeluarkan Direktorat Jenderal Ketenagalistrikkaan Kementerian Energi dan Sumber Daya Mineral, jumlah pelanggan PLN di sektor rumah tangga di Tahun 2016 adalah 59.243.672. Hasil penjualan energi listrik untuk sejumlah pelanggan tersebut adalah 93.634,63 GWh. Dimana konsumsi energi listrik tersebut berasal dari penggunaan peralatan rumah tangga, seperti kulkas, televisi, dispenser, lampu dan AC.

Pengguna listrik sektor rumah tangga tidak mengetahui secara detail peralatan listrik rumah tangga mana yang menghabiskan daya listrik. Sehingga pengguna merasa penggunaan listriknya boros. Besar penggunaan daya listrik dipengaruhi oleh besar beban peralatan listrik dan lama penggunaan peralatan listrik tersebut. Bisa saja peralatan dengan beban daya kecil dengan pengunaan lama mengkonsumsi daya yang lebih besar dibanding dengan peralatan dengan beban daya besar tetapi penggunaannya sebentar.

Internet of Things (IoT) mengacu pada penggunaan teknologi informasi, konektivitas jaringan internet dan sensor yang memungkinkan perangkat yang bukan komputer untuk dapat terhubung satu sama lain melalui jaringan internet. Perangkat ini dapat menghasilkan data, mengirim, menerima, mengumpulkan dan saling tukar menukar data. IoT dapat dimanfaatkan untuk mendukung sistem pemantauan level air [1]. IoT digunakan untuk mengirimkan data level air ke server secara real time. Prototipe sistem monitoring penggunaan energi listrik tiga fasa secara real time dapat didukung dengan menggunakan IoT [2]. IoT yang digunakan pada penelitian ini digunakan untuk mengumpulkan data penggunaan daya setiap peralatan listrik rumah tangga. Data penggunaan daya setiap peralatan listrik rumah tangga ini dapat digunakan untuk memperoleh informasi mengenai peralatan mana saja yang menggunakan daya besar serta informasi mengenai lama waktu penggunaan peralatan tersebut.

Saat ini pelanggan masih sulit untuk memantau penggunaan daya dari setiap peralatan listrik rumah tangga. Sehingga tidak diketahui peralatan mana yang mengkonsumsi energi listrik dalam jumlah besar. Selain itu, juga belum ada sistem yang dapat digunakan untuk memperkirakan lama waktu ketersediaan energi listrik tersebut berdsarkan lama penggunaan peralatan listrik rumah tangga. Untuk itu, diperlukan sistem monitoring penggunaan daya listrik peralatan rumah tangga. Sistem ini dapat dimanfaatkan pelanggan PLN sektor rumah tangga untuk mengetahui peralatan elektronik rumah tangga mana saja yang menggunakan daya besar, sehingga pelanggan dapat mengatur penggunaan peralatan rumah tangga tersebut. Penelitian ini bertujuan untuk membangun sistem monitoring penggunaan daya untuk setiap peralatan elektronik rumah tangga berbasis IoT.

Adityawarman et al. melakukan penelitian yang menghasilkan rancang bangun alat ukur arus menggunakan transformator arus berbasis mikrokontroler ATmega32. Rancang bangun alat ini digunakan untuk mengolah data analog dari transformator arus menjadi data digital. Data tersebut adalah data arus, tegangan dan daya yang ditampilkan secara digital melalui LCD 2x16. Konversi data analog ke digital yang dilakukan pada mikrokontrolermampu membaca arus terbesar sampai 82 A [3].

Perumal et al. melakukan penelitian yang mengusulkan sistem pemantauan air berbasis IoT yang mengukur level air secara real-time. Sensor level air digunakan untuk mendeteksi ketinggian level air berdasarkan parameter yang diinginkan, jika level air mencapai parameter, sinyal data akan dikirimkan secara real-time. Server cloud digunakan untuk menyimpan data. Hasil pengukuran ketinggian air ditampilkan pada dashboard aplikasi prototipe secara jarak jauh [1].

Grgic et al. melakukan penelitian ini telah mengusulkan solusi teknologi IoT untuk real-time monitoring system berbasis web yang ditujukan untuk memantau suhu dan kelembaban dalam proses pengeringan pada sektor pertanian. Fokus penelitian ini adalah bagaimana mekanisme penyampaian data dari sensor ke perangkat end user menggunakan protokol MQTT (Message Queuing Telemetry Transport). Arsitektur sistem digambarkan sebagai arsitektur client-server three-tier dengan tiga layer terpisah, yaitu presentasi, aplikasi dan lapisan basis data [4].

Lestari et al. melakukan penelitian ini menghasilkan prototipe sistem pemantauan energi listrik di gedung G4 Universitas Negeri Malang menggunakan sistem IoT. Prototipe sistem ini telah memungkinkan pengukuran waktu nyata bagi pengguna dan dapat diakses kapan saja. 
Akurasi sistem keseluruhan dilakukan pada pengukuran tegangan tiga fasa, arus tiga fasa dan arus netral dengan hasil akurasi 95,5\% dengan kesalahan rata-rata 4,5\% [2].

Ada empat fitur yang dilihat yaitu pengukur daya, IoT, monitoring, dan area rumah tangga. Pada penelitian pertama oleh Adityawarman mengembangkan alat ukur daya tanpa ada fitur IoT, monitoring. Sedangkan pada penelitian kedua oleh Perumal menggunakan IoT serta monitoring tetapi tidak melakukan pengukuran daya. Penelitian ketiga oleh Grgic menggunakan fitur yang sama dengan penelitian kedua. Pada penelitian keempat oleh Lestari melakukan pengukuran daya serta menggunakan IoT dan monitoring. Sehingga dapat disimpulkan bahwa belum ada penelitian yang menggunakan keempat fitur tersebut secara bersamaan. Untuk itu, pada penelitian ini akan dilakukan pengukuran daya dengan menggunakan IoT serta akan membangun sistem monitoring.

\section{METODE/PERANCANGAN PENELITIAN}

Secara umum dalam penelitian yang akan dilakukan menggunakan metode prototipe. Sebagai implementasi metode tersebut, maka dalam penelitian ini dilakukan dengan tiga tahap utama, yaitu pembuatan sistem, pengumpulan data dan proses monitoring. Gambar 1 berikut adalah alur penelitian tersebut.

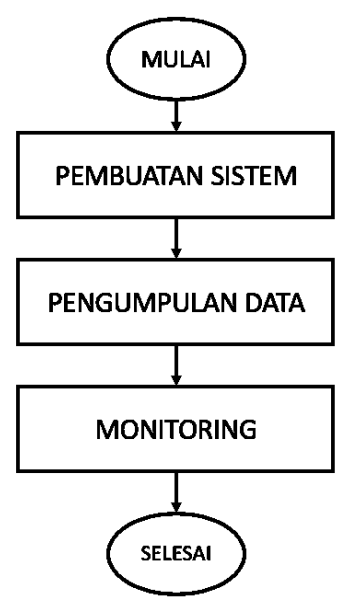

Gambar 1. Metode Penelitian

\subsection{Pembuatan Sistem}

Pada tahap pembuatan sistem ini terdapat beberapa langkah yang dilakukan, yaitu pembuatan alat, perancangan database, perancangan antarmuka.

\subsubsection{Pembuatan Alat}

Pada tahap ini dilakukan perancangan perangkat keras dan perangkat lunak sebagai berikut.

a) Perancangan perangkat keras

Pada dasarnya perangkat keras yang dibuat adalah sebuah wattmeter. Wattmeter ini berfungsi untuk mengukur daya yang dipakai oleh peralatan elektronik rumah tangga seperti televisi, AC, kulkas, setrika, kipas angin, lampu, dan sebagainya. Melalui modul IoT Controller yang dipasang pada wattmeter, data daya peralatan elektronik yang terukur pada wattmeter tersebut akan dikirimkan ke database server. Blok diagram pembuatan alat disajikan dalam Gambar 2 berikut ini. 


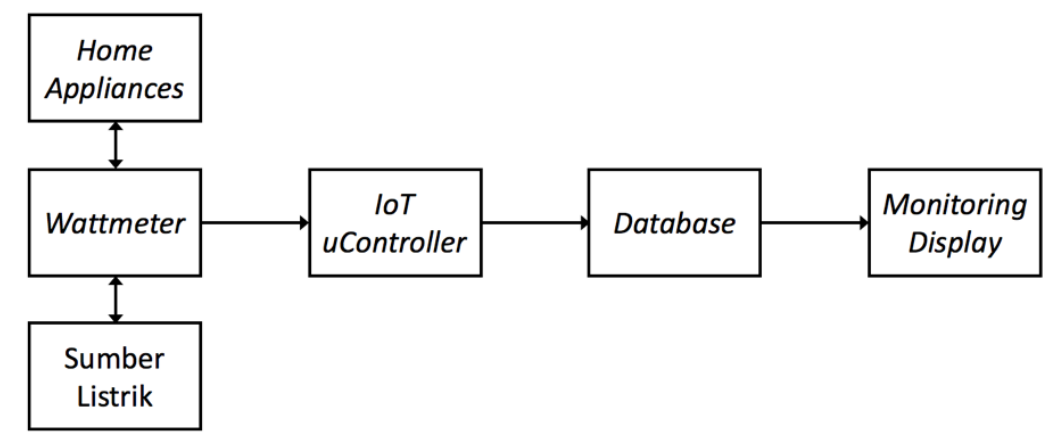

Gambar 2. Blok Diagram Pembuatan Alat

b) Perancangan perangkat lunak

Perangkat lunak yang digunakan adalah sebuah program yang disimpan di dalam IoT controller. Program tersebut adalah program wattmeter yang berfungsi untuk melakukan perhitungan Daya. Alur perancangan perangkat lunak digambarkan melalui flowchart pada Gambar 3.

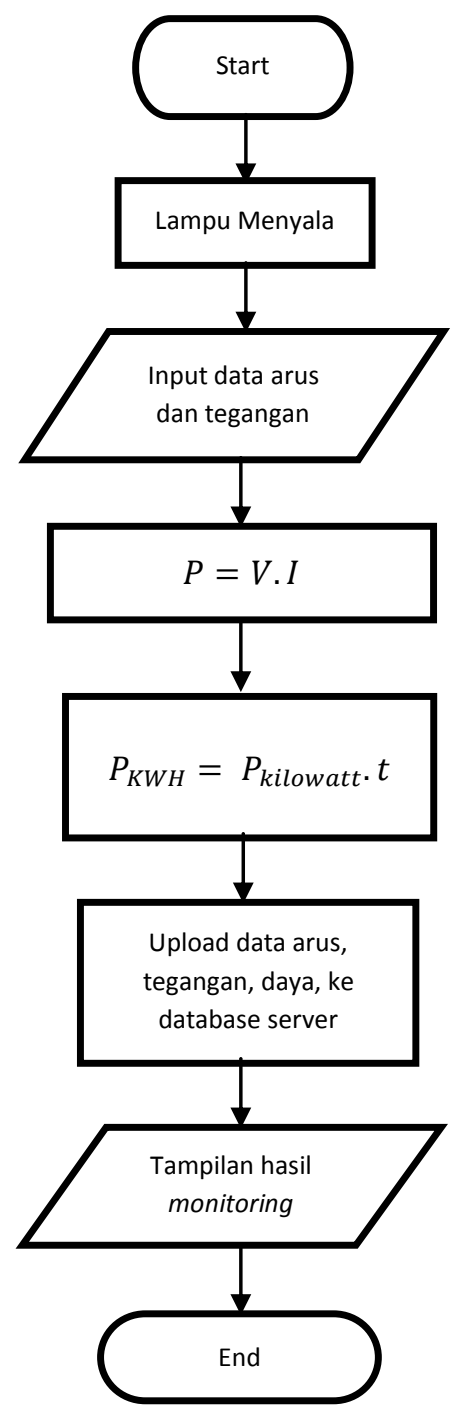

Gambar 3. Flowchart Perancangan Perangkat Lunak 
Data input diperoleh dari data hasil sensing sensor arus dan sensor tegangan. Dari kedua data sensor tersebut dilakukan proses ADC (Analog to Digital Converter) oleh IoT controller sehingga diperoleh data digital berupa besaran arus (I) dan tegangan (V) diskrit. Data inilah yang akan digunakan untuk perhitungan besar daya $(\mathrm{P})$ meggunakan rumus berikut.

$$
\begin{aligned}
& P=V . I \\
& P_{\text {kilowatt }}=P / 1000
\end{aligned}
$$

Data daya tersebut akan dihitung nilai KWH (Kilo Watt Hour), sehingga $P_{K W H}=$ $P_{\text {kilowatt }} \cdot t$; dimana $t$ adalah besaran waktu dalam satuan jam. Data besaran - besaran listrik tersebut diproses oleh program wattmeter dalam IoT controller. Setelah diproses dan diperoleh hasilnya maka data arus, tegangan, daya dan besar daya $(\mathrm{KWH})$ dikirimkan ke database server secara periodik.

\subsubsection{Perancangan Database}

Pada tahap ini akan dibuat database yang akan menyimpan data arus, tegangan dan daya (watt/KWH) setiap peralatan elektronik rumah tangga yang dikirimkan oleh wattmeter. Database ini juga akan mencatat waktu peralatan digunakan, baik ketika peralatan elektronik menyala maupun mati. Data ini digunakan pada proses monitoring. Database yang digunakan memanfaatkan layanan dari thingspeak.com. Thingspeak adalah platform open source internet of things (IoT) untuk menyimpan dan mengambil data dari sebuah IoT controller yang dikirim melalui Internet. Thingspeak akan menampilkan monitoring arus, tegangan dan daya dari peralatan elektronik rumah tangga.

\subsubsection{Perancangan Antarmuka}

Perancangan antarmuka digunakan sebagai tampilan untuk monitoring. Antarmuka dibangun berbasis web. Antarmuka yang digunakan adalah berupa grafik yang menampilkan hubungan antara besaran - besaran arus, tegangan dan daya terhadap waktu.

\subsection{Pengumpulan Data}

Pada tahap pengumpulan data, ada dua jenis data yang dikumpulkan, yaitu data daya yang digunakan oleh setiap peralatan elektronik rumah tangga dan data waktu peralatan elektronik rumah tangga tersebut menyala serta mati. Data-data tersebut didapatkan dari database. Kedua data ini akan digunakan pada proses monitoring.

\subsection{Monitoring}

Pada tahap monitoring, digunakanlah data yang sudah dikumpulkan pada tahap sebelumnya. Pada tahap ini akan ditampilkan informasi yang didapatkan dari pengolahan kedua data tersebut. Informasi yang ditampilkan adalah lama waktu setiap peralatan elektronik menyala dan total daya yang digunakan oleh setiap peralatan elektronik rumah tangga. Informasi lama waktu setiap peralatan elektronik menyala didapatkan dari selisih data waktu peralatan elektronik menyala dan mati. Sedangkan informasi total daya yang digunakan oleh setiap peralatan elektronik rumah tangga diperoleh dari hasil perkalian data daya peralatan elektronik tersebut dengan lama waktu setiap peralatan elektronik.

\section{HASIL DAN PEMBAHASAN}

\subsection{Hasil Prototipe Alat}




\section{JURNAL PETIR}

Vol. 12, No. 1, Maret 2019, P-ISSN 1978-9262, E-ISSN 2655-5018

Pembuatan alat meliputi pembuatan perangkat keras dan pembuatan perangkat lunak. Pembuatan alat ini dimulai dengan melakukan pengukuran arus dan tegangan. Untuk dapat mengukur parameter arus dan tegangan digunakan sensor arus dan tegangan. Sensor arus yang digunakan adalah sensor CT, yang dapat mengukur besar arus bolak-balik (AC). Sensor tegangan yang digunakan adalah sensor ZMPT101B. Sensor tersebut merupakan modul yang digunakan untuk mengukur tegangan AC 1 fasa. Sensor Tegangan ZMPT101B dirancang dengan menggunakan transformator sehingga hanya dapat digunakan untuk membaca tegangan AC. Data sensing dari kedua sensor tersebut diolah menggunakan mikrokontroler NodeMCU. NodeMCU adalah sebuah platform IoT controller yang bersifat open source. NodeMCU terdiri dari perangkat keras berupa System On Chip ESP8266. Beban alat listrik rumah tangga yang dipasang menggunakan sampel berupa lampu. Database dibuat menggunakan Thingspeak. Thingspeak adalah platform open source internet of things (IoT) untuk menyimpan dan mengambil data dari NodeMCU yang dikirim melalui internet. Melalui Thingspeak dapat ditampilkan grafik monitoring arus dan tegangan peralatan elektronik rumah tangga yang digunakan. Selain itu, dalam penelitian ini juga ditampilkan penggunaan daya dan besar penggunaan $\mathrm{KWH}$ dari perhitungan arus dan tegangan. Desain alat yang telah dibuat adalah berdasarkan Gambar 4 berikut ini.

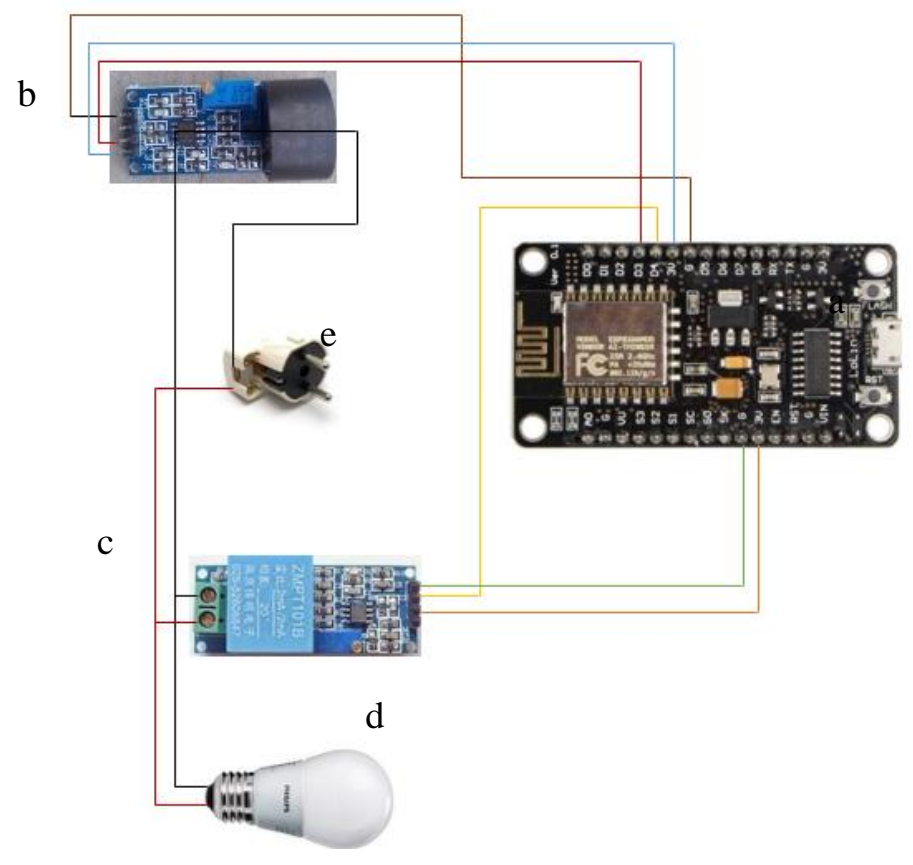

Gambar 4. Hasil Perancangan Alat

Pertama yang harus dilakukan adalah menghubungkan prototipe alat dengan sumber listrik PLN. Sambungan terhadap lampu (d) harus dipastikan benar sehingga lampu menyala. Sensor arus (b) dirangkai secara seri terhadap beban peralatan elektronik rumah tangga. Sedangkan sensor tegangan (c) dirangkai secara pararel terhadap beban. Pin data, VCC dan ground dari sensor dihubungkan ke pin data, VCC dan ground pada NodeMCU (a). NodeMCU dihubungkan ke PC ataupun laptop menggunakan kabel USB untuk menerima program. Setelah program di upload ke NodeMCU, sebagai sumber daya NodeMCU dapat dihubungkan dengan power bank. Sebagai penghubung ke jaringan internet, maka hotspot dari smartphone diaktifkan untuk menghubungkan NodeMCU dengan database server Thingspeak. Hasil monitoring ditampilkan melalui grafik dalam web Thingspeak. Informasi yang disajikan adalah informasi berupa arus, tegangan, dan daya $(\mathrm{KWH})$.

Dari perancangan alat tersebut dihasilkan prototipe alat seperti pada Gambar 5 sebagai berikut. 


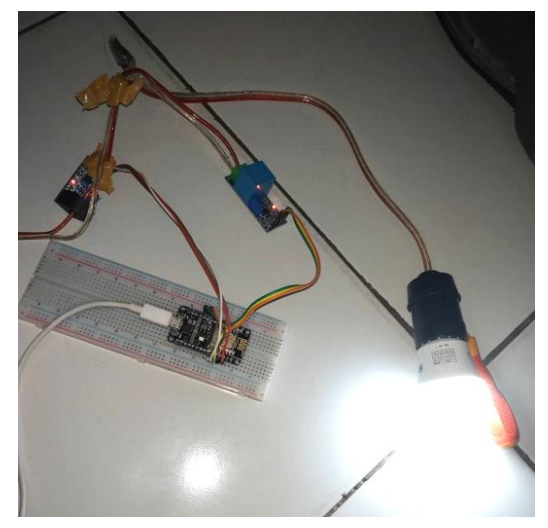

Gambar 5. Prototipe Alat Monitoring Penggunaan Daya Peralatan Elektronik Rumah Tangga

\subsection{Hasil Pembacaan Data Sensor}

Hasil pembacaan sensor arus dan tegangan ditampilkan dari serial monitor. Sebagaimana yang disajikan pada Gambar 6, data arus dan tegangan telah diperoleh. Selain itu hasil perhitungan daya listrik juga ditampilkan. Hasil pembacaan sensor arus dan tegangan dapat dilihat pada Gambar 6 di bawah ini.

$\begin{array}{lll}\text { Arus: } \theta .02 \mathrm{~A} & \text { Tegangan: } 239.77 \mathrm{~V} & \text { Daya: } 3.84 \text { watt Energi: } \theta .00 \mathrm{kw} \text { Energi total: } \theta .00 \mathrm{kwh} \\ \text { Arus: } 0.03 \mathrm{~A} & \text { Tegangan: } 239.77 \mathrm{~V} & \text { Daya: } 7.67 \text { watt Energi: } \theta .01 \mathrm{kw} \text { Energi total: } \theta .00 \mathrm{kwh}\end{array}$

Gambar 6. Hasil Data Arus, Tegangan Dan Daya Dalam Serial Monitor

\subsection{Hasil Antarmuka dan Monitoring}

Monitoring dilakukan melalui antarmuka web pada Thingspeak. Data besaran listrik yang dikirimkan NodeMCU, disimpan ke database yang telah dibuat dalam Thingspeak. Dari database tersebut, data ditampilkan dalam bentuk informasi. Monitoring disajikan dalam bentuk grafik untuk masing - masing besaran listrik. Gambar 7 berikut ini adalah antarmuka monitoring tersebut.

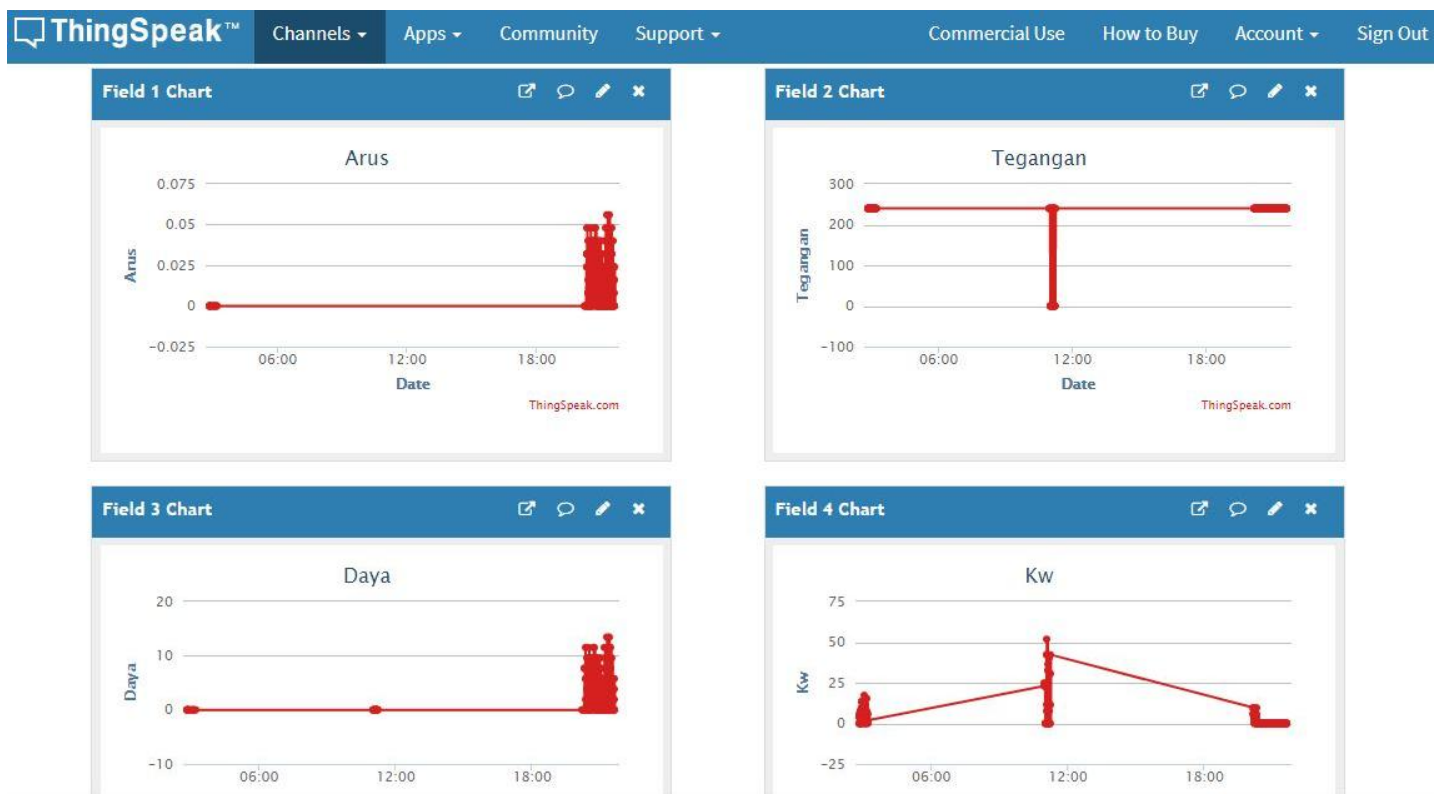




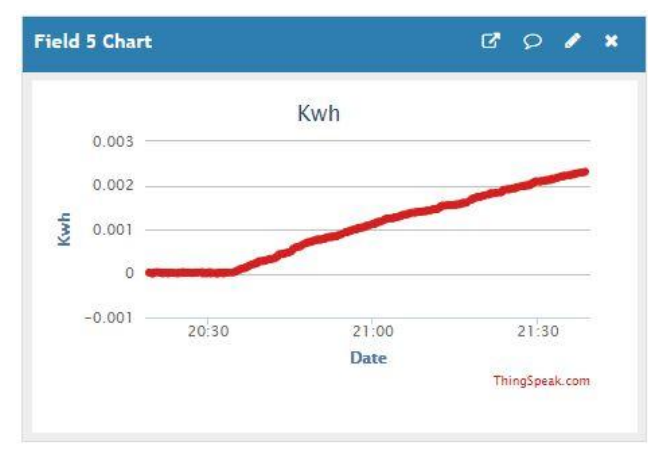

Gambar 7. Antarmuka Monitoring

Grafik monitoring terdiri atas 5 grafik yaitu, field chart 1 untuk monitoring arus, field chart 2 untuk monitoring tegangan, field chart 3 untuk daya, filed chart 4 untuk monitoring daya dalam kilo watt (KW), dan field chart 5 untuk monitoring daya dalam KWH. Grafik arus menunjukkan besar arus yang terukur adalah diatas 0.05 A. Grafik tegangan menunjukkan besar tegangan yang terukur adalah diatas $200 \mathrm{~V}$, akan tetapi kurang dari 250V. Daya KWH terakumulasi sepanjang waktu pengamatan yaitu 60 menit, dimulai pukul 20.30 sampai dengan pukul 21.30. Sehingga, nilai penggunaan daya KWH semakin besar mencapai 0.002 pada pukul 21.30 tersebut. Semakin lama monitoring dilakukan, maka diperoleh nilai KWH yang semakin besar pula.

\subsection{Analisis Data Pengujian}

Dari hasil pembacaan tabel 1 yaitu membandingkan data arus dan tegangan antara pembacaan sensor dengan keterangan pada lampu, maka didapatkan error sebagai berikut:

$I_{\text {Gap }}=I_{\text {keterangan pada lampu }}-I_{\text {pembacaan sensor }}$

$V_{\text {Gap }}=V_{\text {keterangan padalampu }}-V_{\text {pembacaan sensor }}$

Untuk menentukan persentasi kesalahan dapat dihitung dengan rumus sebagai berikut:

Error Arus $(\%)=\frac{I_{\text {Gap }}}{I_{\text {keterangan pada lampu }}} \times 100 \%$
Error Tegangan $(\%)=\frac{V_{\text {Gap }}}{V_{\text {keterangan pada lampu }}} \times 100 \%$

Tabel 1. Hasil Perbandingan Pembacaan Sensor Arus Dan Tegangan

\begin{tabular}{|l|c|c|c|c|}
\hline Nama & $\begin{array}{c}\text { Arus (Pembacaan } \\
\text { Sensor) }\end{array}$ & $\begin{array}{c}\text { Arus } \\
\text { (Keterangan di } \\
\text { Lampu) }\end{array}$ & Perbandingan & Error (\%) \\
\hline Lampu & $0.024 \mathrm{~A}$ & $0.024 \mathrm{~A}$ & $0 \mathrm{~A}$ & 0 \\
\hline Lampu & $239.77 \mathrm{~V}$ & $240 \mathrm{~V}$ & $0.23 \mathrm{~V}$ & 0.0958 \\
\hline
\end{tabular}

Perhitungan daya dilakukan berdasarkan data arus (I) dan tegangan (V). Rumus yang digunakan untuk mendapat daya $(\mathrm{P})$ dan nilai daya $\mathrm{KWH}$ yang diukur digunakan rumus seperti dibawah :

$$
\begin{aligned}
& P=V . I \\
& P_{K W}=P / 1000
\end{aligned}
$$

Maka :

$$
P_{K W H}=P_{K W} \cdot t
$$

Untuk beban lampu, hasil perhitungannya adalah sebagai berikut :

79| Jurnal PETIR 


$$
\begin{aligned}
& I=0,024 \mathrm{~A} \\
& V=239,77 \mathrm{~V} \\
& P=0,024 \times 239.77=5.7 \mathrm{watt} \\
& P_{K W}=5,7 / 1000=0.0057 \mathrm{KW}
\end{aligned}
$$

Karena sensor mendeteksi setiap 10 detik, maka dikalikan 1/360, sehingga:

$$
\begin{aligned}
& P_{K W H}=P_{K W H}+P_{K W} \times 1 / 360 \\
& P_{K W H}=0+0.0057 \times 1 / 360 \\
& P_{K W H}=0.00002 K W H
\end{aligned}
$$

Nilai KWH akan terus bertambah seiring lamanya waktu penggunaan beban listrik.

\section{KESIMPULAN DAN SARAN}

Dari penelitian ini telah dihasilkan prototipe sistem monitoring berbasis internet of things (IoT) pada penggunaan daya listrik peralatan elektronik rumah tangga. Prototipe yang dihasilkan menggunakan IoT controller NodeMCU. Database dan antarmuka menggunakan Thingspeak. Untuk pengembangan selanjutnya, monitoring dapat dilakukan menggunakan database yang dibuat sendiri dan aplikasi web yang independen. Tahap pengujian dapat dilakukan dalam rentang waktu yang lebih lama.

\section{DAFTAR PUSTAKA}

[1] Perumal, T., Sulaiman, M. N., \& Leong, C. Y. (2015). Internet of Things (IoT) enabled water monitoring system. 2015 IEEE 4th Global Conference on Consumer Electronics (GCCE). doi:10.1109/gcce.2015.7398710

[2] Lestari, D., Wahyono, I. D., \& Fadlika, I. (2017). IoT based Electrical Energy Consumption Monitoring System Prototype: Case study in G4 Building Universitas Negeri Malang. 2017 International Conference on Sustainable Information Engineering and Technology (SIET). doi:10.1109/siet.2017.8304161.

[3] Adityawarman, D., Rahajo, Y., Hakim, L. (2014). Rancang Bangun Alat Ukur Arus Menggunakan Transformator Arus Berbasis Mikrokontroler Atmega32. ELECTRICIAN Jurnal Rekayasa dan Teknologi Elektro. Volume 8, No. 2.

[4] Grgic, K., Speh, I., \& Hedi, I. (2016). A web-based IoT solution for monitoring data using MQTT protocol. 2016 International Conference on Smart Systems and Technologies (SST). doi:10.1109/sst.2016.7765668. 